\title{
The Theory of Frame in Rejecting the Rejectionists' Position on the Armenian Genocide
}

\author{
Seda Gasparyan \\ Yerevan State University
}

\begin{abstract}
The focus of the present article is the fabricated nature of some rejectionists' interpretations of the Armenian Genocide brought out by the theory of frame - a reliable instrument widely applicable in cognitive linguistics. Referring to the information accumulated and stored in the memory of humanity and actually reflected in different dictionaries, literary works, official correspondence and documents, the author draws the readers' attention to the background significance of the concepts Armenian and Turk in the cognizance and evaluation of the genocidal events in Western Armenia at the beginning of the $20^{\text {th }}$ century.
\end{abstract}

Key words: the Armenian Genocide, rejectionists' interpretations, cognitive linguistics, the theory of frame, knowledge forming mechanism, human consciousness, barbaric prudence, planned action.

\section{Introduction}

Today, in the $21^{\text {a }}$ century, in the era of human rights, freedoms and responsibilities and the right of nations to self-determination and democracy the issue of the Armenian Genocide is still one of the most debated among officials at the highest echelons of the international community. This is the issue of a genocide carried out about a century ago, but unfortunately still subject to debates due to political considerations and calculations by some. Genocides, regardless of national and time measurements, should, undoubtedly, be constantly discussed, and perpetrators punished, so that further generations of humanity do not even think of executing one or passively watching the powerful in arms do it, so that they learn whence and how genocides emerge and what outcome and consequences they have both for the victims and the executors, as well as for the international community. But if the issue of the Armenian Genocide has been disputed for almost 100 years this, certainly, gives rise to serious reflections.

The international community, particularly the influential political bodies and organizations are never tired of appealing to solidarity and peace. Meanwhile, today's Turkey, the successor of the Ottoman Empire, possesses a substantial part of the habitat of the Armenian people, usurps the property and cultural wealth stolen from them, denies the fact of the Genocide, bullies all over the world, and schemes against the Armenians.' How then can solidarity be achieved between the two countries, in this region, in this world, and eventually in peoples' souls?

The Armenian Genocide has, indeed, been recognized in dozens of countries and by international bodies; they have confirmed it by numerous resolutions and adopted laws. They also condemn the executors and legally prosecute the deniers. However, there are 
countries, political leaders and, unfortunately, "scholars" who deny it, preferring geopolitical, economic and often also personal interests at the expense of justice and morality. sometimes in fear of Turkish threats which actually generate and lead the denial campaign. $^{2}$

\section{The Theory of Frame as an Instrument of Cognizance}

In this linguocognitive examination ${ }^{3}$ of some interpretations of the Armenian Genocide, I intend to make use of the opportunities offered by the theory of frame widely applied in cognitive linguistics and reveal the contrived and fabricated nature of the denial propagated through those interpretations.

The advocated denial, apart from everything else, overlooks a very important factor: the information stored in the memory of not only Armenians but humanity at large, and that information is by no means in favour of the Turks, for the events of the dawn of the century in Western Armenia and the Turkish policy in general have forged certain cognitive models in the field of human perception and left such a deep imprint on the worldview of mankind (first of all on the worldview and cultural outlook of the dispersed Armenian ethnicity) that the neglect of this issue is unacceptable, to say the least. Indeed, in the process of proper perception and interpretation of the events the adequate evaluation of the terms Armenian and Turk has an important background significance, and in this very matter the theory of frame comes to aid. ${ }^{4}$ The cognitive model may be defined as a knowledge forming mechanism, a structure comprising the total of knowledge and experience in the human consciousness which has a situational cultural background; it can contribute to the cognition of various typical situations and phenomena presenting the essential, inherent and possible set of various concepts.

The first stage of investigating the concepts Armenian and Turk reveals the stylistic neutrality of these units. In other words, they are concepts which first and foremost indicate ethnic identity. ${ }^{5}$ Nevertheless, the names of both nations are destined to be interrelated. In the Armenian linguistic conscience the first member of this pair is positive, while the second one is perceived as most negative. This contrast exists in the Turkish mindset as well but with the opposite placement of the members. Yet in the first case it is the result of a bloody collective experience which has engendered an adequate state of mind in Armenians to become an integral part of their national identity, while in the latter it is the result of misleading propaganda caused by the psychological impediments and pragmatic concerns, which together preclude their taking the responsibility for crimes committed by their ancestors. Perhaps it can be said that Armenian and Turk are not merely separate concepts; their contraposition forms a complex conceptual sphere on the cognitive level. And if the concept Turk is presented with conceptual frames like Turk - enemy, Turk - barbarian. Turk - murderer of a nation, which may be generalized by the frame Turk - menace, the concept Armenian in the Armenian linguistic conscience and in general exists in frames like Armenian - creator, Armenian - Christianity / Christian, Armenian - victim, Almenian - grief. I should add here that it took quite a long time for Armenians to overcome the last two complexes.

Deep in the national conscience of Armenians are also rooted the frames Armenian- 
subsistence, Armenian - survival. If we rely upon the image of an Armenian depicted in Byzantine sources (the concepts Armenian and brave were known to be synonymous in the Byzantine Empire ${ }^{6}$ ), the mentioned sequence of conceptual frames will be completed with Armenian - valour the validity of which is also borne out by our national liberation movement, as well as the freedom struggle of Artsakh.

In the semantic structure of the word Turk the following metaphorical meanings are highlighted: "one who is cruel, hardhearted, or tyrannical" " or "applied to anyone having qualities attributed to Turks: a cruel, savage, rigorous, or tyrannical man." "Interestingly, in various surveys, studies and fiction as well these two concepts indicating the two ethnic identities have almost always been presented in two diametrically opposed ways.

As early as in 1853 in an article in the American Daily Tribune Karl Marx expresses the idea that the Turkish presence in Europe seriously hampers the development of the region (the presence of the Turks in Europe is a real obstacle to the development...), and the unreasoned religious fanaticism of the Turkish mob is able to undermine any progress (the fanaticism of Islam supported by the Turkish mob ... to overturn any progress...)."

Another mention of the image of Turk is found in Victor Hugo's poem "L'Enfant" (The Child): "Les Turcs ont passe 'la. Tout est ruine et deuil" (Turks went through there; All is ruin and sorrow).$^{10}$ In these lines the stylistically neutral narrative utterance Turks went through there followed by the utterly negative image all is ruin and sorrow indirectly, yet clearly, draws the picture of a Turk in the reader's imagination - ferocious as it could be that it would brutally trample even the juvenile innocence on its way to suppress the liberation struggle of the Greeks.

It is important to note that the concepts Armenian and Turk have been elucidated in a similar way also in works by other foreign authors and eyewitness testimonies," as well as in voluminous archival and contemporary documents. ${ }^{12}$

On July 16, 1915, US Ambassador to Turkey Henry Morgenthau in a confidential telegram informs the Secretary of State:

Deportation of and excesses against peaceful Armenians are increasing and from harrowing reports of eyewitnesses it appears that a campaign of race extermination is in progress under a pretext of reprisal against rebellion.

Morgenthau's point is that the Armenian people are a peaceful population without any destructive ambitions, whereas they were being treated extremely harshly, and the acts of cruelty were increasing on and on. As the American high-ranking official qualifies, the eyewitness testimonies were heartbreaking and soul-tearing (harrowing), and it was clear that a campaign of extermination of a whole human race was being executed under the Turkish government pretext of retaliation against rebellion.

On August 8, 1915, Ambassador Morgenthau reports about his conversation with Talaat. He informs of the desolated Armenian settlements and the hateful attitude of the Turks towards Armenians. 
$<\ldots>$ they had already disposed of three quarters of them, that there were none left in Billis (Arm. Baghesh - S.G.), Van, Erzerum (Arm. Karin $-S . G$.), and that the hatred was so intense now that they have to finish it.

There are similar testimonies in Austrian documents, too. On September 30, 1915, the Austrian charge d'affaires Count Trauttmansdorff writes to Imperial Foreign Minister Baron Stephan Burian from Constantinople:

With great satisfaction Talaat bey has recently told me that hardly any Armenians were left in Erzerum ...

In 1915, Leslie Davis, US Consul to Turkey, in a message from Harpoot (Arm. Kharberd - S.G.) to Ambassador Morgenthau in Constantinople qualifies the expulsion of Armenians from the region as a very large scale slaughter. He notes that Armenians were designed to be exterminated as a race by a special plan (the plan was to destroy the Armenian race as a race), and that goal was being accomplished with such a cold-blooded and barbaric prudence that they at first did not even realize what was going on.

$<\ldots>$ it has been no secret that the plan was to destroy the Armenian race as a race, but the methods used have been more cold-blooded and barbarous, if not more effective, than I had at first supposed $<\ldots>$

$<. .>$ it seems to be fully established now that practically all who have been sent away from here have been deliberately shot or otherwise killed within one or two days after their departure. This work has not all been done by bands of Kurds but has for the most part been that of the gendarmes who accompanied the people from here or of companies of armed tchetehs (convicts) who have been released from prison for the purpose of murdering the Armenian exiles.

$<\ldots>$ I do not believe there has ever been a massacre in the history of the world so general and thorough as that which is now being perpetrated in this region or that a more fiendish, diabolical scheme has ever been conceived by the mind of man <... >

The US diplomat's speech clearly indicates the widespread nature of the massacres not a mere deportation or expulsion but rather a planned action to eliminate Armenians as a nation. He qualifies the methods applied as more cold-blooded and barbarous than he could ever imagine. By using the unit dellberately (especially of something bad / done on purpose or as a result of careful planning, intentional $\left.{ }^{\prime \prime}\right)$, the US Consul highlights the intentional abhorrence of the genocidal plot which was nothing other than a diabolical machination of the human brain (...I do not believe there has ever been a massacre in the history of the world so general and thorough ... or that a more fiendish, diabolical scheme has ever been conceived by the mind of man...). 
The US Consul also gives a detailed account of the "displaced" population driven through the Harpoot valley (Arm. Kharberd - S.G.) to Deir-el-Zor.

Many Turkish officers and other Turks visited the camps to select the prettiest girls and had their doctors present to examine them <. . >

All in the camp were beyond help.

The quotes make clear for the reader that Turks were enemies of Armenians, yet nothing is said to assure the contrary. It was from the Turkish side that came the gross hatred towards Armenians, and the hatred was so intense that Talaat pronounced with great satisfaction: hardly any Armenians are left in Erzerum (Arm. Karin - S.G.). Pretty Armenian girls were being chosen by Turks after medical examination. And when Leslie Davis writes: all in the camp were beyond help, he writes it about the Armenians, not the Turks. Armenians were the victims smitten with sorrow and confined to grief. Turks were the enemy, barbarous and murderous.

While the massacres were proceeding under the same methods, the Austro-Hungarian Ambassador to Turkey Pallavicini was informing his country's Foreign Minister Ottokar Czernin on the situation in Turkey (as of 22 December, 1917).

Most parts of Armenia, Kurdistan and Mesopotamia have become a theatre of barbarous and horrible sights.

Once again we come across the reference barbarous, this time in the speech of a high-ranking Austro-Hungarian diplomat. In the expression a theatre of barbarous and horrible sights, the adjective barbarous complements the noun sights on the sentence level but on the pragmatic and cognitive levels barbarous refers also to the Turks, for the executors of barbaric scenes are barbarous themselves.

On May 24, 1915, Great Britain, Russia and France issued a joint declaration clearly indicating that Turks and Kurds massacred the Armenians with the approval and assistance given by the Ottoman government:

For about a month the Kurd and Turkish populations of Armenia have been massacring Armenians with the connivance and often assistance of Ottoman authorities. Such massacres took place in middle April (new style) at Erzerum (Arm. Karin - S.G.), Dertchun (Arm. Derjan - S.G.), Eguine, Akn, Bitlis (Arm. Baghesh - S.G.), Mush, Sassun, Zeitun, and throughout Cilicia. Inhabitants of about one hundred villages near Van were all murdered. In that city Armenian quarter is besieged by Kurds. At the same time in Constantinople Ottoman government ill-treats inoffensive Armenian population. In view of those new crimes of Turkey against humanity and civilization, the Allied governments announce publicly to the Sublime-Porte that they will hold personally responsible for these crimes all members of the 
Ottoman government and those of their agents who are implicated in such massacres.

Essentially important is the fact that in international documents the Turkish-Kurdish actions against the Armenians are expressed with verbs like massacre, murder, besiege, ill-treat, whereas the Armenian population is defined with the adjective inoffensive. Such linguistic actualization in speech immediately forms the dichotomy murderer - victim on the cognitive level and still intensifies it by the statement new crimes of Turkey against humanity and civilization which confirms that the Turkish state followed a consistent policy and a regular practice.

Hans von Wangenheim, the Ambassador of Germany to Constantinople, reports to Chancellor Bethmann-Hollweg on July 7, 1915:

Apart from the material damage incurred by the Turkish state as a result of the deportation and expropriation of a hard-working and intelligent element of the population, for which the Kurds and Turks who are preliminarily taking their places do not constitute worthy substitutes, our trade interests and the interests of the German welfare institutions existing in those parts of the country are also being severely damaged.

As described by the German official serving in Turkey, Armenians were a hardworking and intelligent element of the population for which the Kurds and Turks ... did not constitute worthy substitutes. In the context of Wangenheim's statement it is quite visible that Armenians with their industry and gift of creativity have made a significant contribution to the country's economy. This has prompted foreign witnesses and ofticials to speak words of respect and appreciation both for the Armenian people and certain individuals. A case in point is the official letter of Marcel Cachin, a French MP representing the Seine, sent to the Foreign Minister Aristide Briand on December 19, 1915:

The foreign affairs committee of the chamber was informed by respectable Mr. Aharonyan about the new attempt of extermination of the whole mation. The tragic story of this prominent Armenian was confirmed by the reports of American and Swiss missionaries and consuls, and they are involved in the last book of honorable lord Bryce.

In another official Austrian document, sent from Constantinople on September 30, 1915, the disastrous state of the Armenians in Ottoman Turkey is mentioned:

The situation of the Armenians in Turkey is hopeless; it seems that the Turkish government has planned the extermination of the entire Armenian race. 
The passages show that there were more than enough grounds for the formation of the frame Armenian - victim. and this is borne out by the use of such statements as the new attempt of extermination of the whole nation, the tragic story, the situation of the Armenians in Tirkey is hopeless, etc. Among many others, they come to testify that the occurrence of the frame Armenian - victim was not a mere chance, but based on individual and national experience. There were no obstacles for the Turkish leaders to realize their plan and achieve their goal, fast and final. The butcher himself (Talaat Pasha - the Interior Minister of the Ottoman Empire) states in his order-messages that the Armenocide should be executed however tragic the means may be; and there must be no hesitation or objection to his demands. Thus, for example,

September 3, 1915

To the Prefecture of Aleppo:

We advise that you include the women and children also in the orders which have been previously prescribed as to be applied to the males of the intended persons. Select employees of confidence for these duties.

Minister of the Interior, TALAAT

September 16

To the Prefecture of Aleppo:

Their existence (the existence of Armenians - S. G.) must come to an end, however tragic the means may be; and no regard must be paid to either age or sex, or to conscientious scruples.

Minister of the Interior, TALAAT

Another order-message by Talaat reveals the Turkish attitude towards orphaned Armenian children who were being treated in the same cruel way for they were rendered as at least harmful.

We are informed that certain orphanages which have opened also admitted the children of the Armenians. Should this be done through ignorance of our real purpose, or because of contempt of it, the Government will view the feeding of such children or any effort to prolong their lives as an act completely opposite to its purpose, since it regards the survival of these children as detrimental. I recommend the orphanages not to receive such children; and no attempts are to be made to establish special orphanages for them.

Minister of the Interior, TALAAT

The phrase our real purpose and the statement will view as an act completely opposite to its purpose directly point to the fact that Turkey acted with purposeful cruelty, and it is obvious enough that it was a plan agreed upon, supported and executed by the government. 
The examples provided make the description of Turks quite clear - murderous, barbarous, extremely cruel, full of hatred and violence, enslaving though possessing lower intellectual qualities and work skills than those they subject to slaughter. The linguistic expression of all this is the direct reflection of the existence of the frames Turk-barharian, Turk - assassin / murderer of a nation. Quite the opposite of this are the characteristics given to the Armenians by the authors of the passages adduced above: harmless, hard-working and intelligent, respectable, but tormented and helpless against the brutal force which devours in order to extirpate.

One of the main reasons for the decision of eradicating Armenians was the difference in religious identity. There is plenty of evidence spreading light on this aspect of the issue, too. The following is a quote from the German Ambassador Wangenheim's report (June 17, 1915) to the Head of his government, Chancellor Bethmann-Hollweg.

... it becomes obvious that deportation of the Armenians arises not only from military necessity. The internal minister Talaat bey told about it honestly to doctor Mortsman, who is employed at the empire embassy now. Talaat said: "The Sublime Porte intends to make use of the world war for cleaning the whole country from internal enemies, the local Christians $<\ldots>$ "

Mr. Wangenheim's report overtly shows that it is the Turkish side that puts a "mark" of hostility between themselves and the "internal enemies," i.e. the local Christians. Although in the initial phase of the Genocide an exception was granted to Catholic Armenians because the Turks acknowledged that Catholicism penetrated into Armenia from the Western countries, however, this did not prevent them from breaking the promise, and most of the exceptions were revoked once again. The Special Envoy Wolff Metternich's report (July 10, 1916) to Chancellor Bethmann-Hollweg gives evidence of the fact that the Catholic and Protestant Armenians were eventually also being subjected to clearing up, although the Porte had repeatedly assured that the latter would not be deported:

But they are also clearing up among the old established population and among the Catholic and Protestant Armenians, although the Porte has repeatedly assured that the latter will be spared. The remainder will be deported partly to Mesopotamia, partly converted to Islam. <...>

In Marasch and Aleppo the deportation is in full action; in Marasch not even the families were spared who had formerly been granted special permits by the Minister of the Interior. In Angora the Vali, Reschid Bey, well-known for his deeds in Diarbekir, is engaged in tracing the last Armenians (solely Catholics) and expelling them. The remaining Protestant and Catholic Armenians in Eskischehir and in the areas around Ismir are being treated in the same way. Despite all official denials, Islamization plays a great role in this last phase of the persecution of the 
Armenians. Already at the end of April, Father Christoffel from Siwas (Arm. Sebastia - S.G.) reported that he had met the last Christian Armenians in Eregli (Arm. Aragil - S.G.); from there to Siwas the Armenians had been completely cleared away, "either deported, or converted or murdered. There was not one Armenian sound to be heard anywhere."

The following are excerpts from the Austro-Hungarian Ambassador Pallavicini's report to the Foreign Minister Ottokar Czernin on December 22, 1917. Once again they confirm the Turks' religious fanaticism and the decisive role of Turkish religious expansionism underlying the execution of both the Armenian Genocide and the Genocide of other Christian national minorities, subjects of the Ottoman state, for the sole reason that a Christian meant somebody different, and that was not to be tolerated.

Vilayet of Diarbekir - Veren Shehir is a small town in the neighborhood of Urfa (Arm. Urha, Yedesia - S.G.) and had a population consisting of 1400 Armenian and 140 Assyrian families; the 400 families entirely were exiled at the beginning of the summer. All the men were slaughtered. Rich families with women and children were exterminated.

...Diocese of Sgert (Arm. Sghert - S.G.): there were 450 Armenian, 120 Caldian, 30 Jakobian families here. All of them were pillaged, slaughtered or deported...

$<$... Urfa, formerly Yedesia, king Abgar's capital, had a more cruel fase. The Christians, the number of which was above 25000, were cruelly pillaged, massacred and tortured three times, the quarters of the town were bombarded and destroyed. Their bishop and priests together with the prominent citizens of the town, nearly 500 people in number, were put into prison before being killed, it is said, then they were exiled to Diarbekir but they were massacred on the way. Thousands of orphan slaves are now in Mohammedan families: great number of these unfortunates are starving in the streets of Urfa. The Mohammedans of Urfa together with the authorities personally took part in massacres, they looted the property of the Christians.

In other parts of Turkey the fate of Christians is indefinite. They are always subjected to the threat of being killed.

The Apostolic Christian faith has always been the most important component of the Armenian national identity since $301 \mathrm{AD}$ when Armenia, first among the countries of the world, adopted Christianity as a state religion. The Armenian Apostolic Christianity and the Armenian language, being the two pillars of the Armenian national identity, ${ }^{14}$ have always been in the focus of our enemies' attention." Thus, it is not a mere chance that Armenian Christian faith, church and its leaders have been under special scrutiny of the Turkish authorities. The church was the active circle around which the Armenian people 
gathered especially under lost statehood. This was the reason for the special Turkish hatred towards the Armenian spiritual leaders. This fact is confirmed by Smirnov's (the Russian Envoy to Cairo) report to the Russian Foreign Minister Sazonov on June 25, 1915, where we can read:

\section{Especially the Armenian clergy are pursued cruelly:} the priests are haunted, tortured, their nails are pulled out.

The significant value of Christianity to the Armenian nation accounts for the fact that the concept Armenian in the Armenian self-identification and perception is first and foremost associated with the basic, underlying frame Armenian - Christianity / Christian through which in the prevailing majority of cases an ethnic Armenian is perceived also by non-Armenians.

\section{Conclusion}

The illustrations given make the Turkish condemnable behaviour quite tangible. They come to confirm the importance of the above-mentioned conceptual models in the cognizance and evaluation of Armenian-Turkish relations and the actual social-psychological background of the Armenian Genocide. They also reveal the explicit artificiality and vainness of promoting denial on false and fabricated grounds.

The documentary material presented above draws our attention to another fact as well: it is no secret at all that the world powers knew what was going on in Ottoman Turkey during the massacres. In their official statements, documents, reports, correspondence representatives of these countries have given detailed descriptions and true evaluations calling the events by their proper names. Some of those governments have been more honest in their evaluations then than they actually are today, in the 21 st century. As for Turkey, it denies, dessembles and deludes today just as it used to do yesterday.

\section{Notes:}

1. A vivid illustration of the vicious mechanisms of behaviour inherited by the present Turkish government from their predecessors is Turkey's active support and participation in the recent events in Kessab - a region in Syria inhabited by Christian population, prevailingly Armenian.

<http://armenpress.am/eng/news/755363/turkish-intellectuals-condemn-ongoingevents-in-kessab.html> Retrieved [15.04. 2014, 18:30]

2. Cf.: R. Melson, A Theoretical Inquiry into the Armenian Massacres of 1894-1896. /I Comparative Studies in Society and History, XXIV, 3 (July 1892), p. 481-509; S. Shaw, History of the Ottoman Empire and Modern Turkey, Vol. 1. Cambridge: CUP, 1976; G. Lewy, The Armenian Massacres in Ottoman Turkey: A Disputed Genocide, Salt Lake City: University of Utah Press, 2004; R. Suny, Looking Toward Ararat: Armenia in Modern History, Bloomington and Indianapolis: Indiana University 
Press, 1993; A Question of Genocide. Armenians and Turks at the End of the Ottomann Empire / Ed. R. Suny, F. Göçek, N. Naimark. Oxford: OUP, 2011, etc.

3. In surveys on problems of gnoseology and cognitive linguistics in particular, the anthropocentric approach and the cognitive orientation of studies allow to reveal the correlation of linguistic phenomena and the human knowledge accumulated from the objective reality by personal experience as well as expose the mechanisms underlying the cognitive processes. As a result, speech is viewed as a process reflecting public behaviour which rests upon cognitive structures fixed in human brain and deduces the "inner mind" formed therein. Particularly in the matters of cognitive-pragmatic aspect the key to their solution is in the intersection of lexicology and a number of other sciences. Cf. Е.С. Кубрякова, Парадигмы научного знания в лингвистике и еe современный статус [Paradigmy nauchnogo znaniya $v$ lingvistike $i$ yeyo sovremennyy status] // Изв. РАН Сер. Лит-ры и я3., т. 53, 122. М., 1994; С.

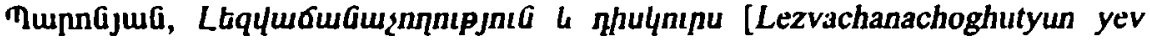
diskurs], bn., 6 M< hpuun., 2011; etc.

4. Cognitive models form the world outlook of a human and direct his or her behaviour. On this issue cf. Е.С. Кубрякова, В.З. Демьянков, Щ.Г. Панкрац, Л.Г. Лузина, Краткий словарь когнитивных териинов, [Kratkiy slovar'kognitivnykh terminov]. М., МГУ, 1997; М. Минский, Фрейиы для представления знаний [Freimy dlya predstavleniya znaniv]. М., изд-во Энергия, 1979; Ч. Филлмор, Фреймы и семантика понимания [Freimy i semantika ponimaniya] // Новое в зарубежной лингвистике. Когнитивные аспекты языка [Novoe v zarubezhnoy lingvistike. Kognitivnye aspekty yazyka], вып. XXIII. М., изд-во Прогресc, 1988.

5. In most English dictionaries the mentioned units are interpreted as follows:

Armenian - a member of a people dwelling chiefly in Armenia but also dispersed throughout the Middle East and emigrated to the New World; Turk - a member of any of numerous Asiatic peoples speaking Turkic languages who live in the region ranging from the Adriatic to the Okhotsk and who are racially mixed but are held to have risen in the Altai mountains and western Siberia. (Cf. Webster's Third New International Dictionary. Massachusetts: Merriam-Webster Inc. Publishers, 1981, p.119, p. 2465).

6. Cf. «f Jnıquaqulua unpjnınGitn» ["Byuzandakan aghbyurner"], h. $b$,

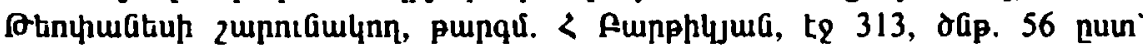

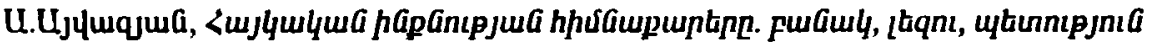
[Haykakan inknutyan himnakarery: banak, lezu, petutyun], Gn., 2007, tq 28.

7. Webster's Third New International Dictionary. Massachusetts: Merriam-Webster Inc. Publishers, 1981, p. 2465:

8. The Shorter Oxford English Dictionary on Historical Principles, vol. 2. Oxford: Clarindon Press, 1978, p. 2382.

9. <http://ziontruth.blogspot.com/2007/11/was-karl-marx-zionist-neocon-batyeor.html $>$ Retrieved [15.04. 2014, 18:17]

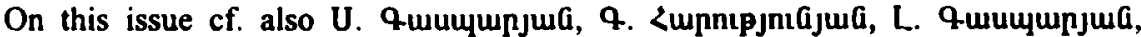

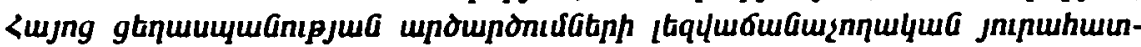

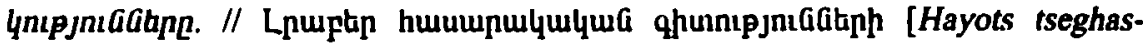


panutyan artsartsumneri lezvachanachoghakan yurahatkutyunnery], 1(633), bp., « QUU QhunntpjntG hnuun., 2012, te 184-199.

10. V. Hugo, Les Orientales. / Ed. Charles Gosselin, Paris, 1829. Cf. also A. Ekrem, L'image du Turc dans les Orientales de Victor Hugo. // Francofoni 2003, N 15, pp. 91-100.

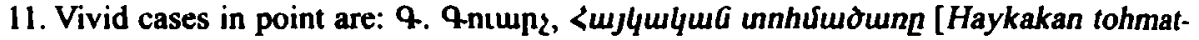

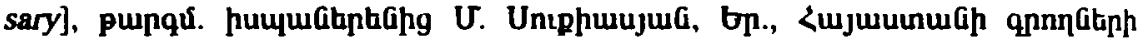
úpnıpjwa hnuin., 2005; 9. Antwn?, lwjng qunul [Hayots ktak], punqu. puuquatptapg U. Unıphuujua, bn., Gワर hnuun., 2011; Г. Гуарч, Белая гора [ Belaya gora ], перевод с испанского В. Гуренко. М., изд-во Фитон XXI, 2013; U.

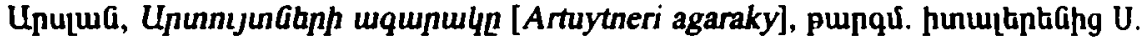
¿mpnipjntajua, bn., Uwhul Mupple hpuun., 2007; etc.

12. The documentary English texts used in this article have been derived from the website of the Museum-Institute of the Armenian Genocide: <http://genocide-museum.am/eng/ >

13. Cf. Longman Dictionary of English Language and Culture. Addison Wesley Longman, 1998, p. 340.

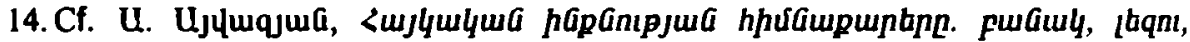
uttunnipjniG [Haykakan inknutyan himnakarery: banak, lezu, petutyun], Gp., Lnumula hpuin., 2007, tq 47-97.

15. Nevertheless, the Armenian people rose every time and defended their vital values also by force, when necessary. A brilliant illustration is the Vardanants struggle to death headed by military leader Vardan Mamikonyan in 451 AD.

\section{References:}

1. Ayvazyan, A. (2007) Haykakan inknutyan hinmakarery: banak, lezu, petutyun. Yerevan: Lusakn Publishers.

2. (2011) A Question of Genocide. Armenians and Turks at the End of the Ottomann Empire. / Ed. by R. Suny, F. Gûcek, N. Naimark. Oxford: OUP.

3. Fillmore, Ch. (1988) Freymy $i$ semantika ponimani'a [Фреймы и семанмика понимания]. // Novoe v zarubezhnoy lingvistike. Kognitivnye aspekty yazyka, issue XXIII. M.: Progress Publishers.

4. Gasparyan, S.; Harutyunyan, G.; Gasparyan, L. (2012) Hayots tseghaspanutyan artsartsumneri lezvachanachoghakan yurahatkutyunnery. // Lraber hasarakakan gitutyunneri, N 1 (633). Yerevan: Gitutyun Press of RA NAS.

5. Kubr'akova, E.S. (1994) Paradigmy nauchnogo znani'a v lingvistike i yeyo sovremennyy status. // Izv. RAN, seri'a Literatury i yazyka, Vol. 53, 122. M.

6. Kubr'akova, E.S.; Dem'ankov, V. Z.; Pankrats, U.G.; Luzina, L.G. (1997) Kratkiy slovar 'kognitivnykh terminov. M.: MSU.

7. Lewy, G. (2004) The Armenian Massacre in Ottoman Turkey: A Disputed Genocide. Salt Lake City: University of Utah Press.

8. (1994) Longman Dictionary of English Language and Culture. England: Pearson Education Limited. 
9. Melson R. A Theoretical Inquiry into the Armenian Massacres of 1894-1896. // Comparative Studies in Society and History, XXIV, 3 July, 1892.

10. Minskiy, M. (1979) Freimy dl'a predstavleni'a znaniy. M.: Energi'a.

11. Paronyan, Sh. (2011) Lezvachanachoghutyun yev diskurs. Yerevan: YSU Press.

12. Shaw, S. (1976) History of the Ottoman Empire and Modern Turkey. Vol. 1. Cambridge: CUP.

13. Suny, R. (1993) Looking Toward Ararat: Armenia in Modern History. Bloomington and Indianapolis: Indiana University Press.

14. (1978) The Shorter Oxford English Dictionary on Historical Principles. Vol. 2. Oxford: Clarindon Press.

15. (1981) Webster's Third New International Dictionary. Massachusetts: MerriamWebster Inc. Publishers.

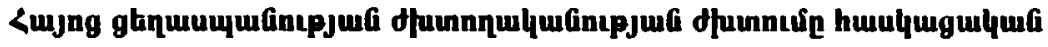

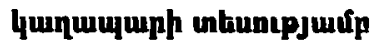

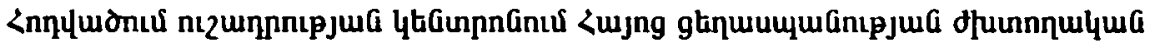

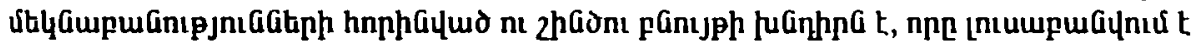

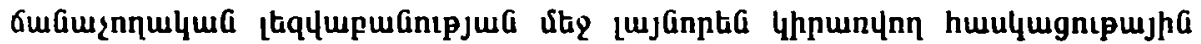

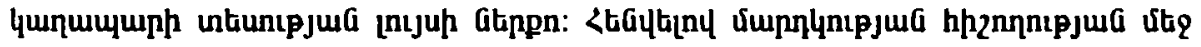

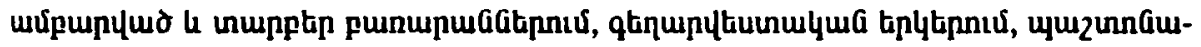

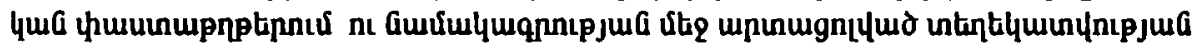

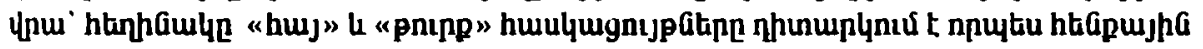

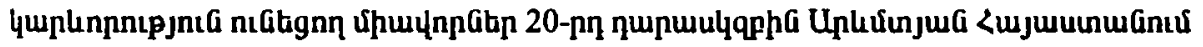

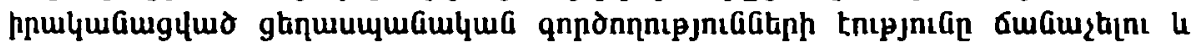
tzưunhun undlenptint hungneu:

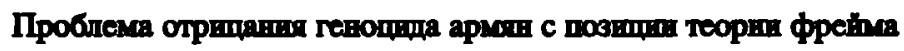

Статья посвящена изучению сфабрикованности интерпретаций одной из величайших трагедий человечества - Геноцида армян в западной Армении в начале прошлого века. Применением приниипов теории фрейма, широко используемой в когнитивной лингвистике, автор статьи обращает внимание на фоновую значнмость концегтов “армянин” и “турок” в восприятин, пониманни и правдивой интерпретации событий, произошедших 1915 году и в последующий пернод. 